Contents lists available at http://ejournal.uin-suska.ac.id

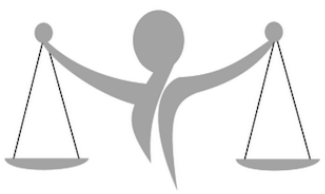

Al-Ittizaan: Jurnal Bimbingan Konseling Islam

ISSN: $2620-3820$

Journal homepage: http://ejournal.uin-suska.ac.id/index.php/alittizaan

\title{
Implementasi Bimbingan Sosial Dalam Penyesuaian Diri Bagi Lanjut Usia Di UPT Pelayanan Sosial Tresna Werdha Khusnul Khotimah Pekanbaru
}

\author{
1, Zulamri ${ }^{2}$ \\ ${ }^{1,2}$ Universitas Islam Negeri Sultan Syarif Kasim Riau
}

\begin{tabular}{l}
\hline Info Artikel \\
\hline Article history: \\
Received Jun $12^{\text {th }}, 2018$ \\
Revised Aug $20^{\text {th }}, 2018$ \\
Accepted Aug $26^{\text {th }}, 2018$ \\
\hline
\end{tabular}

\section{Kata Kunci:}

Bimbingan Sosial

Penyesuaian

Lanjut usia

\begin{abstract}
ABSTRAK
Pada umumnya lanjut usia merupakan bagian akhir dari perkembangan manusia yang selalu identik dengan berbagai macam permasalahan. Selain perubahan dari segi fisik, lanjut usia juga mengalami perubahan psikologis seperti kehilangan pasangan, teman-teman dekat, perasaan kehilangan karena ditinggal oleh anak-anaknya dan perubahan peran. Perubahan psikologis tersebut sering memengaruhi tingkah laku lanjut usia. Banyaknya lansia yang mengalami permasalahan dalam penyesuaian diri dengan lingkungan sekitar, teman sebaya dan lain-lain. Hal ini memerlukan bimbingan sosial untuk mengatasi permasalahan yang dihadapi lansia tersebut. Peran psikolog dalam mengembangkan kemampuan penyesuaian diri lansia di UPT Pelayanan Sosial Tresna Werdha Khusnul Khotimah Pekanbaru sangat berpengaruh. Tujuan dari penelitian ini adalah untuk mengetahui implementasi bimbingan sosial dalam penyesuaian diri bagi lanjut usia di UPT Pelayanan Sosial Tresna Werdha Khusnul Khotimah Pekanbaru. Penelitian ini menggunakan metode penelitian kualitatif dengan dengan tipe deskriptif yang menjelaskan dan menafsirkan data yang ada. Informan dalam penelitian ini adalah psikolog di UPT Pelayanan Sosial Tresna Werdha Khusnul Khotimah Pekanbaru dan koordinator/pembimbing sosial di UPT Pelayanan Sosial Tresna Werdha Khusnul Khotimah Pekanbaru. Teknik pengumpulan data yang digunakan untuk mendapatkan data dan informasi adalah menggunakan observasi, wawancara, dan dokumentasi. Dari hasil penelitian, penulis dapat menyimpulkan bahwa implementasi bimbingan sosial dalam penyesuaian diri bagi lanjut usia di UPT Pelayanan Sosial Tresna Werdha Khusnul Khotimah Pekanbaru menggunakan bimbingan secara langsung seperti pencerahan (ceramah), dikusi (menyampaikan pendapat), dan tanya jawab (wawancara).
\end{abstract}

(C) 2019 The Authors. Published by UIN Sultan Syarif Kasim Riau.

This is an open access article under the CC BY license (https://creativecommons.org/licenses/by/4.0)

\section{Nama Penulis:}

Alpianti ${ }^{1}$, Zulamri ${ }^{2}$

1) 2) Universitas Islam Negeri Sultan Syarif Kasim Riau

Email: 4lpianti95penti@gmail.com

\section{Pendahuluan}

Menurut Islam, pada mulanya manusia ini berada dalam suatu lingkungan kecil, sehingga hubungan sosial pun masih berada dalam ruang lingkup terbatas, yaitu dalam keluarga. Semakin lama semakin berkembang baiklah umat manusia dan menyebar kemana-mana, sehingga menjadi masyarakat. Dalam kehidupan bermasyarakat sering terjadi proses saling mempengaruhi silih berganti antar anggota-anggota 
masyarakat itu, kemudian timbul antar orang-orang itu suatu pola kebudayaan, dan mereka bertingkah laku menurut sejumlah aturan, hukum, adat serta nilai-nilai yang mereka patuhi demi untuk mencapai penyelesaian bagi persoalan-persoalan hidup mereka, agar mereka dapat tetap bertahan dalam jalan yang sehat dari segi kejiwaan dan sosial.

Manusia secara naluriah memerlukan orang lain dalam kehidupannya. Begitu manusia dilahirkan, ia memerlukan "berkomunikasi" dengan ibunya untuk bisa bertahan hidup (meminta perlindungan dan bantuan makanan). Pada hakikatnya manusia adalah makhluk sosial yang selalu berinteraksi dengan individu lainnya karena individu satu dengan yang lainnya saling membutuhkan, maka sebagai makhluk sosial yang hidup bermasyarakat, seseorang selalu diharapkan dapat berperilaku sesuai dengan tuntutan dan harapan masyarakat.

Untuk dapat mencapai kesejahteraan hidup yang hidup yang didambakan seseorang harus tumbuh dan berkembang menjadi manusia matang, mandiri dan dapat menyesuaikan diri dengan lingkungan sesuai dengan perkembangan hidupnya. Perkembangan rentang hidup manusia merupakan proses yang berkesinambungan. Mulai dari masa konsepsi berlanjut kemasa sesudah lahir, masa bayi anak-anak, remaja, dewasa hingga menjadi lansia. Perubahan-perubahan jasmaniah yang terjadi sepanjang hidup, mempengaruhi sikap, proses kognitif, dan perilaku individu (Desmita 2006). Seperti halnya pada lansia, pada kemampuan kognitif, lansia tidak mampu mengembangkan potensi dalam dirinya sampai ke taraf yang dibutuhkan untuk menghadapi tuntutan sosial secara memadai.

Pada umumnya para lansia merupakan bagian dari generasi tua yang akan menghadapi masalah. Selain perubahan dari segi fisik, lansia juga mengalami perubahan psikologis seperti kehilangan pasangan, temanteman dekat (relation loneliness), sindrom sarang hampa (empty nest syndrome) yaitu perasaan kehilangan karena ditinggal oleh anak-anaknya dan perubahan peran. Perubahan psikologis tersebut sering mempengaruhi tingkah laku lansia (Gunarsa 2004).

Para teoritis psikoanalisis, Sigmund Freud dan Carl Jung, melihat lansia mirip dengan kanak-kanak. Freud, misalnya, percaya bahwa usia lanjut, kembali pada kecenderungan-kecenderungan narsistik masa kanakkanak awal. Jung mangatakan pada usia lanjut, pikiran tenggelam jauh dibawah ketidaksadaran, sedikit kontak dengan realitas pada usia lanjut mungkin terjadi (W 2002).

Lansia juga sering kali disebut usia orang yang sudah tidak produktif lagi, kondisi fisik rata-rata sudah menurun sehingga dalam keadaan uzur ini berbagai permasalahan mudah datang, dengan demikian di usia lanjut ini terkadang muncul semacam pemikiran bahwa mereka pada sisa-sisa umur menunggu kematian (Jalaluddin 2002).

Hal ini sesuai dengan firman Allah pada surat Al-hajj ayat 5 sebagai berikut:

Artinya: "Dan di antara kamu ada yang diwafatkan dan (adapula) di antara kamu yang dipanjangkan umurnya sampai pikun, supaya dia tidak melihat lagi sesuatupun yang dahulunya telah diketahuinya” (RI 2001).

Keberadaan lingkungan keluarga dan sosial yang menerima lansia juga akan memberikan kontribusi positif bagi perkembangan sosio-emosional lansia, namun begitu pula sebaliknya jika lingkungan keluarga dan sosial menolaknya atau tidak memberikan ruang hidup atau ruang interaksi bagi mereka maka tentunya memberikan dampak negatif bagi kelangsungan hidup lansia.

Mencermati banyaknya populasi dan permasalahan yang dialami lansia, serta penanganannya, maka diperlukan pengembangan pelayanan bagi lansia, agar berbagai pelayanan yang dilaksanakan dapat lebih mampu memenuhi kebutuhan dan mengatasi permasalahannya, serta dapat mengantisipasi masalah sosial yang mungkin timbul. Upaya-upaya aktif untuk memperbaiki kesan sosial terhadap lansia dan menghasilkan kondisikondisi kehidupan yang baik juga harus ditingkatkan.

Salah satu upayanya ialah bimbingan sosial, uraian bimbingan sosial mencakup pada pengembangan kemampuan bersosialisasi, baik dalam keluarga maupun masyarakat, pengembangan kemampuan secara harmonis dengan teman sebaya, kemampuan berkomunikasi secara baik, kemampuan menerima dan menyampaikan pendapat (Hibana S. Rachman 2003).

UPT Pelayanan Sosial Tresna Werdha Khusnul Khotimah Pekanbaru memberikan bantuan kepada lansia dengan berbagai bimbingan, yaitu bimbingan sosial, bimbingan keagamaan, dan bimbingan psikologis. Kegiatan bimbingan sosial tersebut dilakukan setiap hari sesuai dengan jadwal yang telah ditentukan. Bimbingan sosial yang diberikan bertujuan agar lansia merasa terbebas dari permasalahan hidupnya, mengenali dirinya dengan baik, serta menjalankan kehidupan dengan sewajarnya. Di UPT Pelayanan Sosial Tresna Werdha Khusnul Khotimah Pekanbaru, pembimbing menangani permasalahan lansia seperti tekanan mental akibat ditempatkan oleh keluarganya ke panti tersebut, adanya ketidaksesuaian dengan teman satu wisma, kurang merasa nyaman dengan kesehatan fisik yang semakin menurun sehingga menyebabkan mereka tidak leluasa dalam beraktivitas dan sebagainya.

Namun jika dilihat dari fenomena-fenomena belakangan ini para lansia tidak mendapatkan bantuan ataupun bimbingan yang semestinya diberikan. Di UPT pelayanan sosial lain pun terjadi hal-hal yang memilukan dan meresahkan lansia sebagai penghuni panti. Berdasarkan hal tersebut diatas maka penulis tertarik untuk mengadakan penelitian dengan judul "Implementasi Bimbingan Sosial Dalam Penyesuaian Diri Bagi Lanjut Usia Di Upt Pelayanan Sosial Tresna Werdha Khusnul Khotimah Pekanbaru”. 


\section{Metode Penelitian}

Jenis penelitian yang penulis gunakan adalah penelitian yang bersifat kualitatif, sebagai prosedur penelitian yang menghasilkan data deskriptif berupa data lisan dari orang-orang, dan perilaku-perilaku yang diamati (Moleong 2012). Penelitian ini akan mendeskripsikan tentang implementasi bimbingan sosial dalam penyesuaian diri bagi lanjut usia di UPT Pelayanan Sosial Tresna Werdha Khusnul Khotimah Pekanbaru.

Lokasi penelitian adalah di UPT Pelayanan Sosial Panti Jompo Tresna Werdha Khusnul Khotimah Dinas Sosial Provinsi Riau J1. KH. Nasution No. 116 Pekanbaru. Sementara waktu penelitian ini dilakukan 3 bulan yaitu pada bulan Maret sampai dengan bulan Mei. Dalam sumber data penelitian dapat digolongkan menjadi dua yaitu (Tika 2006):

a. Data Primer

Data primer adalah data yang dihimpun secara langsung dari informasi dan diolah sendiri oleh peneliti. Data primer diperoleh dari hasil observasi partisipasi dan wawancara terhadap informan.

b. Data Sekunder

Data sekunder adalah data yang diperoleh secara tidak langsung yaitu dari hasil dokumentasi dan data-data yang tersedia dari berbagai pihak atau instansi terkait dengan penelitian.

Informan penelitian adalah subjek yang memahami informasi tentang penelitian sebagai pelaku atau orang lain yang memahami obyek penelitian (Burhan 2008). Merupakan orang yang benar-benar mengetahui permasalahan yang akan di teliti. Sesuai dengan judul penelitian tentang implementasi bimbingan sosial dalam penyesuaian diri bagi lanjut usia di UPT Pelayanan Sosial Tresna Werdha Khusnul Khotimah Pekanbaru. Dan yang menjadi informan yaitu pembimbing atau koordinator UPT. Pelayanan Sosial Panti Jompo Tresna Werdha Khusnul Khotimah Dinas Sosial Provinsi Riau yaitu Bapak Susilo, psikolog yaitu Ibu Yulia Wardani, S.Psi., M.Psi., Psikolog. Di UPT Pelayanan Sosial Panti Jompo Tresna Werdha Khusnul Khotimah Dinas Sosial Provinsi Riau. Dan 7 orang reponden.

Validitas data di dalam penelitian kualitatif berbeda dengan kuantitatif, jika kuantitatif menggunakan validitas dan reliabilitas, dalam penelitian kualitatif menggunakan konsep keabsahan data. Keabsahan data akan meningkatkan kedalaman peneliti baik mengenai fenomena yang diteliti maupun konteks di mana fenomena itu muncul, jadi pemahaman yang mendalam atas fenomena yang diteliti merupakan nilai yang terkandung dalam penelitian kualitatif. Sebab, penelitian kualitatif lahir untuk menangkap arti (meaning) atau memahami gejala, peristiwa, fakta, kejadian, realitas atau masalah tertentu mengenai peristiwa observasi dan kemanusiaan dengan kompleksitasnya secara mendalam.

\section{Hasil dan Pembahasan}

Bimbingan sosial adalah layanan bimbingan yang diberikan kepada individu untuk mengenal lingkungannya sehingga mampu bersosialisasi dengan baik dan menjadi pribadi yang bertanggung jawab (Hibana S. Rachman 2003). Dalam interaksi sosial, karena setiap orang mempunyai bakat, minat, kepentingan dan berbagai perbedaan individu lainnya, konflik sosial bisa terjadi. Kepentingan individu bisa berbenturan dengan kondisi kelompok. Kepentingan kelompok bisa berbenturan dengan kondisi kelompok lainnya. Benturan-benturan kepentingan serupa itu dapat menimbulkan masalah bagi individu.

Dalam pembahasan ini dilakukan analisis tentang pengembangan kemampuan bakat dan minat bagi lanjut usia di UPT Pelayanan Sosial Tresna Werdha Khusnul Khotimah Pekanbaru. Pembahasan ini meliputi kegiatan keterampilan yang dilakukan setiap hari Selasa. Kegiatan keterampilan ini dilakukan agar lansia di UPT Pelayanan Sosial Tresna Werdha Khusnul Khotimah Pekanbaru akan mendatangkan rasa berguna dan rasa puas di lingkungan panti sosial tersebut. Para lansia juga diharapkan mampu bersosialisasi sesama teman sebaya di panti tersebut.

Kemudian hasil analisis tentang mengembangkan kemampuan bakat dan minat lansia juga sangat menarik, karena hal ini sesuai dengan hasil wawancara peneliti dengan psikolog di UPT Pelayanan sosial Tresna Werdha Khusnul Khotimah Pekanbaru yaitu Ibu Yulia Wardani, S.Psi., M,Psi., Psikolog. Dalam hal ini di jelaskan bahwa agar kemampuan minat dan bakat lansia ini berkembang di adakan kegiatan, dan dari kegiatan tersebut lansia bisa mengembangkan bakat mereka masing-masing. Karena para lansia tersebut memerlukan waktu untuk mengembangkan bakat dan minatnya masing-masing.

Hal ini sesuai dengan pendapat para ahli menurut Darmojo mengatakan bahwa kegiatan-kegiatan dan hobi beraneka ragam memungkinkan usia lanjut masih merasa bermanfaat bagi keluarga dan masyarakat. Perasaan ini telah cukup dapat memberi dorongan hidup bagi usia lanjut sehingga tak akan mengalami apa yang 
di sebut pension-stress atau post power syndrome. Pemberdayaan bagi usia lanjut, apalagi yang sifatnya produktif sangatlah penting, karena akan mendatangkan rasa berguna dan rasa puas (Suardiman 2010).

1. Materi Pokok Bimbingan Sosial

Dari data yang peneliti sajikan pada hasil wawancara di atas, menjelaskan bahwa untuk mengembangakan komunikasi lansia secara baik adalah dengan cara mengajak berbicara dan disesuaikan dengan situasi dan kondisi lansia pada saat itu, karena kalau mereka sedang mengalami masalah beban pikiran susah untuk diajak berkomunikasi secara individu dan mereka para lansia berbeda-beda karakter. Dan untuk mengajarkan atau membentuk komunikasi yang baik dengan lansia, rata-rata dengan mengajarkan berbahasa Indonesia yang baik dan benar, karena disini masih banyak lansia yang masih kurang untuk berbahasa Indonesia secara fasih.

Dalam hal ini analisis penulis tentang pengembangan kemampuan untuk menjalin hubungan harmonis dengan teman sebaya antar lansia ini sebagian memang belum bisa untuk menjalin hubungan tersebut, karena lansia ini pada hakikatnya sudah menua dan untuk hal yang seperti ini kebanyakan lansia cenderung mementingkan diri sendiri. Tetapi sebagian lansia memang bisa menjaga hubungan yang harmonis tersebut. Hal ini sesuai dengan sifat dan karakter masing-masing lansia.

Hal ini sesuai dengan pendapat Musthafa Fahmy mengatakan bahwa tidak kurang pentingnya penerimaan terhadap orang lain, dari pada penerimaan terhadap diri sendiri dan penerimaan orang lain terhadap diri. Di antara tanda kedewasaan adalah penerimaan terhadap orang dalam berbagai pendapat, kepercayaan dan kebangsaannya, dan tidak menghiraukan kekurangan dan kelemahan mereka, serta menhindari kritikan terhadap mereka. Sebagaimana diketahui bahwa orang yang selalu merendahkan orang lain, dialah yang tidak memperoleh penerimaan orang terhadap dirinya dan gagal dalam penerimaan dirinya (Fahmy 1982).

1. Tujuan Bimbingan Sosial

Berdasarkan wawancara peneliti bahwasannya tujuan bimbingan yang diterapkan di UPT Pelayanan Sosial Tresna Werdha Khusnul Khotimah Pekanbaru adalah agar lansia bisa menyelesaikan masalah dengan sendirinya tanpa menimbulkan masalah yang baru serta menjadi pribadi yang bertanggung jawab. Selanjutnya bimbingan sosial ini bertujuan untuk mencegah dan memelihara situasi dan kondisi kehidupan bermasyarakat atau di lingkungan sekitar.

Menurut penulis tujuan bimbingan tersebut sangat bagus, karena berdasarkan teori yang penulis kaji sebelumnya mengatakan bahwa bimbingan sosial tersebut bertujuan untuk membantu lansia memahami timbulnya masalah-masalah berkaitan dengan kehidupan bermasyarakat dan membantu lansia mencegah dan memelihara situasi dan kondisi kehidupan bermasyarakat.

2. Asas-asas Bimbingan Sosial

Berdasarkan wawancara peneliti dengan pembimbing dan psikolog pada UPT Pelayanan Sosial Tresna Werdha Khusnul Khotimah Pekanbaru bahwasanya asas-asas tersebut adalah landasan yang dijadikan pegangan dalam bimbingan sosial tersebut, landasan tersebut ialah landasan keagamaan, landasan kemanusiaan dan landasan musawarah.

Menurut peneliti dalam hasil wawancara kepada pembimbing dan psikolog bahwa bimbingan sosial di UPT Pelayanan Sosial Tresna Werdha Khusnul Khotimah Pekanbaru berdasarkan asas-asas yang ada, hal ini telah dijelaskan bahwa bimbingan sosial tersebut berpegang pada landasan yang sudah diterapkan dalam panti. Juga diperlukan oleh lansia agar merasa aman dilingkungan sekitar.

Selanjutnya dalam hal ini peneliti menganalisa bahwa landasan tersebut berkaitan dengan asas-asas yang peneliti cantumkan pada teori. Hal ini menunjukan bahwa yang peneliti kaji sesuai dengan permasalahan yang dikaji. Asas-asas tersebut ialah asas kebahagiaan dunia dan akhirat, asas komunikasi dan musyawarah, asas kasih sayang, asas menghargai dan menghormati dan asas rasa aman.

3. Objek Bimbingan Sosial

Menurut hasil wawancara peneliti dengan pembimbing dan Psikolog mengenai upaya mencegah dan mengatasi masalah penesuaian diri, disini adalah objek dari bimbingan sosial tersebut bagaimana upaya agar lansia bisa menyesuaikan diri dengan lingkungan sekitar. Hal ini penulis melihat bahwasanya dalam bimbingan sosial adalah salah satu cara agar lansia mampu untuk menyesuaikan diri dengan lingkungannya. Dan cara lainnya ialah selalu mengajak lansia tersebut untuk berbicara agar terbiasa dilingkungannya. 
Selanjutnya penulis menganalisa untuk mencegah masalah penyesuaian diri lansia tersebut dengan mengajak lansia untuk ikut serta dalam kegiatan-kegiatan di panti, agar di setiap kegiatan tersebut lansia bisa melangsungkan kehidupannya dan saling berbicara dengan lansia lainnya. Dan selalu bersama-sama dengan para lansia tersebut, masalah penyesuaian diri lansia dapat teratasi dengan sangat baik.

Ternyata bahwa apabila orang ingin menyesuaikan diri dalam hidup, ia harus belajar cara-cara mengenali persoalan-persoalan dan cara mengatasinya. Dan ia juga harus mengetahui bagaimana memilih cara penyelesaian yang tepat bagi setiap masalah. Dan hendaknya ia mengambil langkah-langkah positif yang tepat dalam penyelesaiannya. Dan sebaliknya, kita menemukan pula orang yang terganggu kejiwaannya, ia mundur ke belakang, masuk ke alam khayal, sehingga ia tidak menemukan permasalahan, atau dengan mudah ia dapat mengatasinya (Fahmy 1982).

Menurut penulis, berdasarkan wawacara dengan peneliti dan psikolog mengenai upaya mencegah dan mengatasi masalah hubungan antar tetangga. Masalah ini agar bisa diatasi secara baik dengan cara saling menjaga hubungan silaturahmi. Sebelumnya penulis juga telah menjelaskan bahwa penyesuaian diri itu bisa diatasi jika lansia mengikuti kegitan-kegiatan di panti dan mereka saling berbicara satu sama lain. Masalah antar tetangga juga bisa di atasi dengan cara saling menjaga hubungan silaturahmi. Maka terciptalah hubungan antar tetangga yang harmonis. Hal ini sesuai dengan teori yang peneliti kaji sebelumnya.

\section{Kesimpulan}

Dari hasil penelitian mengenai implementasi bimbingan sosial dalam penyesuaian diri bagi lanjut usia di UPT Pelayanan Sosial Tresna Werdha Khusnul Khotimah Pekanbaru, dapat disimpulkan bahwa telah sesuai dengan kajian peneliti dengan yang diterapkan di lapangan. Karena bimbingan sosial merupakan bantuan yang diberikan kepada lansia untuk mengatasi permasalahan yang dihadapinya tanpa menimbulkan masalah yang baru serta menjadi pribadi yang bertanggung jawab. Sehingga lansia mampu mengatasi masalah sosialnya, dan dapat menyesuaikan diri dengan lingkungan sekitar tanpa ketergantungan dengan orang lain.

Dalam hal ini hasil wawancara dan observasi di UPT Pelayanan Sosial Tresna Werdha Khusnul Khotimah Pekanbaru telah terlaksana bimbingan sosial sesuai yang diharapkan lansia di UPT tersebut. Yang bertujuan agar lansia mampu menyesuaikan diri dengan lingkungan sekitar. Dengan adanya bimbingan sosial secara rutin pada setiap minggunya para lansia semakin mampu untuk menyesuaikan dirinya. Sehingga dapat dikatakan bimbingan sosial di UPT Pelayanan social Tresna Werdha Khusnul Khotimah Pekanbaru dapat dikatakan berhasil ditetapkan.

\section{Saran}

Dari hasil penelitian dan analisis yang penulis lakukan, maka dapat dikemukakan beberapa saran untuk dijadikan pertimbangan bagi pihak yang terlibat dalam proses pemberian bimbingan sosial dalam penyesuaian diri lanjut usia di UPT Pelayanan Sosial Tresna Werdha Khusnul Khotimah Pekanbaru. Untuk meningkatkan dan menjaga stabilitas serta keefektifan dalam memberikan bimbingan bimbingan sosial dalam penyesuaian diri lanjut usia di UPT Pelayanan Sosial Tresna Werdha Khusnul Khotimah Pekanbaru maka dikemukakan beberapa saran sebagai berikut:

1. Diharapkan kepada pihak UPT Pelayanan Sosial Tresna Werdha Khusnul Khotimah Pekanbaru agar tetap menjalankan kegiatan pemberian bantuan bimbingan sosial terhadap lansia dan memberikan bimbingan sosial secara efektif dalam penyesuaian diri lanjut usia, agar lansia mampu untuk menyesuaikan diri dengan lingkungan sekitar.

2. Diharapkan kepada pembimbing atau Psikolog untuk meningkatkan kegiatan-kegiatan unggulan atau kiranya dapat terus melakukan perbaikan dan evaluasi terhadap kegiatan dalam rangka implementasi bimbingan sosial dalam penyesuaian diri bagi lanjut usia di UPT Pelayanan Sosial Tresna Werdha Khusnul Khotimah Pekanbaru. Sehingga lansia mampu untuk menyesuaikan diri serta menjadi pribadi yang lebik baik.

\section{Daftar Rujukan}

Burhan, Bungin. 2008. Penelitian Kualitatif: Komunikasi, Ekonomi, Kebijakan Publik, Dan Ilmu Sosial Lainnya. Jakarta: Kencana.

Desmita. 2006. Psiklogis Perkembangan. Bandung: PT. Rosdakarya. 
Fahmy, Prof. Dr. Musthafa. 1982. Penyesuaian Diri. Jakarta: N. V. Bulan Bintang.

Gunarsa, Singgih D. 2004. Bunga Rampai Psikologi Perkembangan Dari Anak Sampai Usia Lanjut. Jakarta: PT BPK Gunung Mulia.

Hibana S. Rachman. 2003. Bimbingan Dan Konseling Pola 17. Yogyakarta: UCY Press.

Jalaluddin. 2002. Psikologi Agama. Jakarta: PT Raja Grafindo Persada.

Moleong, Lexy J. 2012. Metodologi Penelitian Kualitatif. Bandung: PT Remaja Rosdakarya.

RI, Departemen Agama. 2001. Al-Quran Dan Terjemahannya. Semarang: Semarang: PT Toha Putra.

Suardiman, Siti Partini. 2010. Psikologi Usia Lanjut,. Yogyakarta: Gajah Mada University Pres s.

Tika, Moh. Prabundu. 2006. Metodologi Riset Bisnis. Jakarta: Bumi Aksara.

W, Santrock John. 2002. Perkembangan Masa Hidup. 5th ed. ed. Juda Danamik. Jakarta: Erlangga. 